Review

\title{
Review of Heating Methods for Rural Houses in China
}

\author{
Guozhong Zheng * and Wentao Bu \\ School of Energy, Power and Mechanical Engineering, North China Electric Power University, \\ Baoding 071003, China; buwentao@ncepu.edu.cn \\ * Correspondence: zhengguozhong@ncepu.edu.cn; Tel.: +86-812-752-2443
}

Received: 3 November 2018; Accepted: 30 November 2018; Published: 4 December 2018 updates

\begin{abstract}
With the continuous development of the social economy, residents living in rural China pay more attention to the heating quality and require a comfortable and healthy indoor thermal environment in winter. The existing traditional heating methods cannot meet the high-quality heating demands. Although the new heating methods based on clean energy can satisfy the needs of residents in terms of energy saving, environmental protection and thermal comfort, they have not been widely used due to their high initial investment, the misunderstanding of principal functions and the perceived difficulty of application. This study firstly summarizes various available heating methods for rural areas from aspects of technical characteristics, environmental friendliness, indoor comfort, and economy. Then it gives advice for government and relevant institutions to increase publicity for new heating methods. It aims to provide a theoretical basis and feasible suggestions for the selection of heating methods for rural residents in China. It also aims to provide theoretical policy making references for the transformation of the original rural heating methods.
\end{abstract}

Keywords: rural house; heating methods; thermal comfort; coupled system

\section{Introduction}

With the continuous development of the social economy, the income of rural residents has increased, and residents have put forward new requirements for heating in winter. They have started to pay more attention to the quality of their heating and to pursue a more comfortable indoor thermal environment. Therefore, a significant increase in the rural total energy consumption has been taking place and a series of environmental problems are becoming more and more serious [1,2]. Consequently, widespread attention is paid to rural heating.

In the rural areas, heating for houses shows the following characteristics. Firstly, due to the vast decentralized single buildings commonly found in these locations, the heating of rural houses relies on self sufficiency [3]. Secondly, most rural houses have a shape coefficient (the ratio between the external skin surfaces and the inner volume of the building) of 0.7 or more, which represents a greater energy consumption for the unit building area. Thirdly, rural houses are constructed by farmers relying on their experiences rather than detailed and geographically targeted design and construction, and heat insulation materials are rarely adopted [1,4-7]. Finally, heating forms have distinctive regional characteristics. In northern areas, heating is usually performed by means of Kang, coal fired boilers, heat pumped split air conditioners, and electric heaters. In the southern region (the hot summer and cold winter regions of the Yangtze River basin), heating is conducted by stoves, electric blankets, electric heating, and heat pumped split air conditioners [4]. According to the investigation, traditional heating methods such as Kang and stoves still occupy a dominant position [8,9] in rural areas of China.

At present, winter heating mainly relies on coal [10-12]. In the process of burning coal (especially inferior coal), a large amount of pollutant mixture is produced, including smoke, greenhouse 
gases and other acid gases. These scattered emissions are heavily distributed in rural areas. Space heating is the largest emission source among all daily practices, and it accounts for around $64 \%$ of the total $\mathrm{CO}_{2}$ emissions in the lowest $25 \%$ income group, and $59 \%$ in the highest income group [13]. Correspondingly, the overall trends in $\mathrm{CO}_{2}$ emissions from energy consumption in rural China included significant increased from 152.22 million tons in 2001 to 283.58 million tons in 2008 at an annual growth rate of $9.29 \%$, and the annual growth rate of per capita $\mathrm{CO}_{2}$ emissions was nearly 2 times faster than that of urban China $[14,15]$. Moreover, with the improvement of living standards, the per capita housing area is continuously increasing, therefore the use of coal continues to increase [16]. Based on the statistics, the total construction area in rural areas of China is approximately 24 billion $\mathrm{m}^{2}$ and the annual heating consumption of coal is approximately 190 million tons (equivalent to 136 million tons of standard coal), showing a rapid growth trend [17]. It is predicted that by the year 2020, commodity energy involving at least 300-400 million tons of standard coal will be required for the heating of northern rural houses [17].

To address the shortcomings of traditional heating methods, many studies have proposed practical suggestions for improving traditional heating methods. Meanwhile, new heating methods based on clean energy, e.g., solar hot water heating systems, heat pumps based on air sources and ground sources, and gas boiler hot water heating systems have gradually been developed and used for heating. Although there are adequate heating methods, it is difficult for rural residents to decide which method to adopt that would provide a satisfying heating performance [18]. In addition, lack of scientific expertise about the design and construction of heating systems also leads to a significant reduction in the actual effect of heating systems. Furthermore, there are many subjective and objective drivers and barriers behind the reconstruction of the existing heating methods and the adoption of new heating methods, such as sociodemographic characteristics (i.e., income, household size, age and etc.), functional and psychological barriers. All of these problems affect the wide application of new heating methods in rural areas of China.

For purposes of creating a comfortable indoor thermal environment and reducing environmental pollution and $\mathrm{CO}_{2}$ emission, the traditional heating methods and the new heating methods based on clean energy are introduced and analyzed in this paper from the perspectives of environmental friendliness, indoor thermal comfort, technical aspects and the economy respectively. Then the scientific references on the selection of heating methods are given. In addition, the theoretical basis for the transition of rural heating methods is provided for policy making.

\section{Traditional Rural Heating Methods}

\subsection{Kang Heating Method}

Kang is composed of a fire mouth, Kang body and chimney (Figure 1a) [19]. The fire mouth is a heat source, the Kang body is a heat dissipating component, and the chimney is a smoke exhaust component [20]. The high temperature smoke generates at the fire mouth and then passes through the inside of the Kang body, thus the surface temperature of the body rises and the heat is transferred from the body surface to the indoor air. Finally, the smoke is discharged through the chimney after full heat exchange with the Kang body [20]. The heat gain of the body is related to the flow of the smoke in the flue and the residence time of the smoke in the flue. The amount of heat exchange between the body and the indoor air is related to the structure of the body, heat storage materials and other factors [21]. Kang has the following unique features and obvious advantages: low cost, simple construction, flexible heating, health care assistance and disease prevention [22]. However, the traditional Kang also has shortcomings, e.g., low combustion efficiency, large fuel consumption, low thermal comfort and large combustion pollution [23], which can no longer satisfy people's new demands on the indoor thermal environment. 


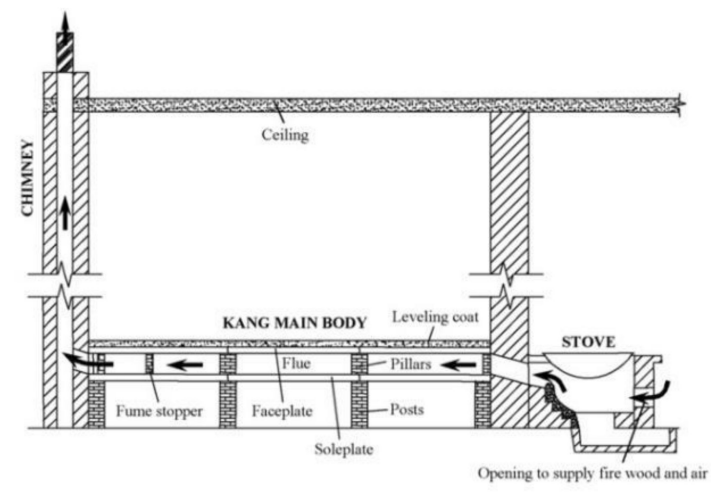

(a) Elevated Kang system

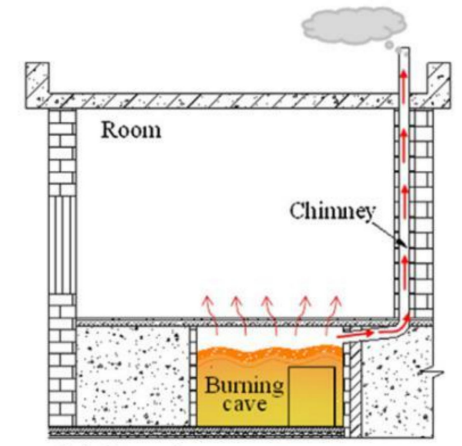

(c) Burning cave system

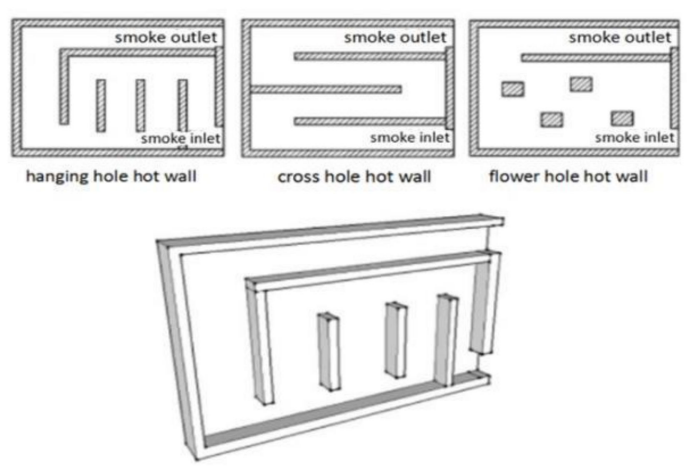

(b) Internal structure of hot wall

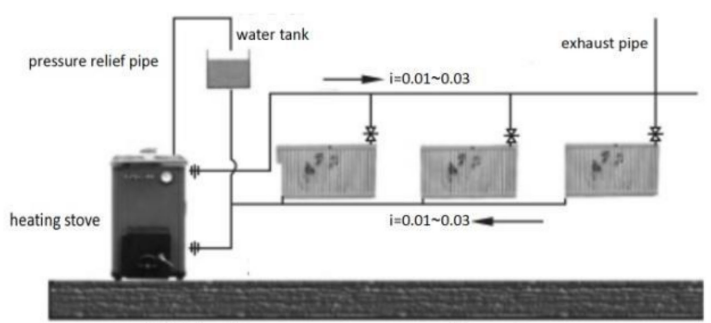

(d) Indigenous water heating system

Figure 1. Schematic diagrams of traditional rural heating methods.

Kang are mainly divided into: traditional grounded Kang, the relatively new elevated Kang and the new hot wall Kang [24]. The grounded Kang is directly built into the floor and the main body is constructed using brick [19]. In contrast, the elevated Kang is suspended from the floor supported by several pillars, and there is a 10 to $20 \mathrm{~cm}$ air layer, which not only enhances heat dissipation, but also prevents heat loss from the ground [24]. The hot wall Kang is a new type of Kang in which the structure of the common grounded Kang is optimized, and a hot wall is added [25]. The height of the hot wall is lower than that of the Kang's faceplate, and together both form the new Kang heating system. The hot wall Kang can be used alone or in combination with other heating methods, making the heating of rural houses more flexible [26]. In the cold northern rural areas, as the main heating facilities, Kang is particularly important because of its local temperature and thermal comfort [23]. Also, radiation is its main heat transfer form, accounting for about $60 \%$ of the total heat dissipation. The Kang's uniformity of the surface temperature and the instant thermal property are improved by the effect of the added hot wall. According to the field measure data, even under the conditions of low outdoor temperature in winter, the indoor temperature can still be maintained at $15^{\circ} \mathrm{C}$ to $18{ }^{\circ} \mathrm{C}$, which is $13{ }^{\circ} \mathrm{C}$ higher than that of the house without heating and about $20^{\circ} \mathrm{C}$ higher than the outdoor temperature, therefore the improved hot wall Kang shows a good thermal performance [9]. However, in the case of combination use of the hot wall Kang, $26.3 \%$ of the energy carried by the smoke is lost through the chimney, $8.27 \%$ of heat loss is through the hot wall, and $3.17 \%$ is through the earth ash layer [26]. Obviously, a large amount of heat is wasted in Kang heating, therefore heating energy consumption significantly increases to ensure comfortable indoor heating.

Some research on Kang heating has been conducted in terms of the structure, heat efficiency and thermal comfort. The research has mostly proved feasible in practical applications. Ren et al. [27] proposed an integrated technical plan for heating and ventilation of Kang. The outdoor air was preheated by Kang and then transferred to the room through a duct. It effectively solved the problem of poor indoor air quality caused by the reduction of air pressure inside the room. Zhang et al. [21] installed a fume stopper in which the height of its lower soleplate was $36 \mathrm{~cm}$ above the ground. 
The results indicated that the heat transfer performance and the indoor temperature were impacted by the turbulence, the flow process of the smoke, and the height of the elevated Kang. Therefore, the design principle of the flue is to extend the flow process of smoke in the flue, increase the turbulence, and reasonably set the height of the elevated Kang.

\subsection{Hot Wall Heating Method}

The hot wall is commonly used for rural heating in cold northern China [28]. It takes the principles of thermal fluids, chimney effect, heat storage and heat radiation as the theoretical basis to meet the heating requirements of one room and one wall [29]. The hot wall (Figure 1b) is a rectangular brick wall. In the wall, many empty holes allow smoke to collude inside, then heat is transferred to both sides [28]. It serves not only as a heater but also as an indoor partition.

The hot wall is a kind of original ecological heating system, which can use biomass such as straw and fuel wood produced in rural areas. Meanwhile, it is an easy heating technology built with simply available materials, and it has large surface area to transfer heat and store heat. In cold winters, the indoor temperature can rise in a shorter time compared with the heating method of Kang. Correspondingly, the hot wall will cool rapidly after the stove or other heat sources stop supplying heat. It is because that the bricks used for building hot walls have a limited storage capacity, as a result, heat in the smoke cannot be fully absorbed and stored, and the hot walls have bad thermal inertia [30]. Moreover, the hot walls are currently built on basis of experience, and they usually have the shortcomings of high exhaust smoke temperature, high energy consumption, and low energy utilization efficiency [31].

In order to realize a better heating performance of the hot walls, scholars have proposed practical and effective solutions to improve the heating performance of the hot walls, e.g., using materials with larger heat storage coefficients to build the hot walls, laying the packaged phase change heat storage materials on the outer surface of the hot walls, or improving the internal cavity structure from the perspectives of separation distance and sectional area of the flue [28]. According to the characteristics of the hot wall heating, an encapsulation box of tetradeconic acid with a phase change temperature of $54-55{ }^{\circ} \mathrm{C}$ was simulated for heating and natural cooling. The results showed that the phase change material could effectively regulate the indoor temperature of houses using the hot wall heating. In addition, the greater the thickness of the box was, the greater the amount of encapsulated tetradeconic acid was, and the greater the heat storage capacity and the heating capacity to the surrounding space were [32]. Furthermore, in the case of installing the heat conducting fins, the internal filling of the copper foam would make the temperature distribution in the box more uniform, meanwhile, the complete phase change time of the phase change material in the large thickness box could be significantly reduced. As a result, the problem of slow heat absorption for the larger capacity encapsulation box was effectively solved [33]. Wang and $\mathrm{Hu}$ [30] proposed a detachable heat storage encapsulation device with phase change materials for a hot wall in a cold area. The device could be embedded to make full use of the residual heat of the smoke to adjust the indoor temperature, and to solve the problems of severe dust accumulation and the failure of heat storage devices caused by thermal expansion of phase change materials. Through calculation and simulation, the heat absorbed by the wall filled with the phase change heat storage material $\left(\mathrm{Na}_{2} \mathrm{HPO}_{4} \cdot 12 \mathrm{H}_{2} \mathrm{O}\right)$ was approximately 1.38 times that by the traditional hot wall, and the heat absorbed by the phase change material accounted for $31.31 \%$ of the total heat. The phase change heat storage wall could effectively store heat and maintain a comfortable indoor temperature during heating intervals. The research mentioned above commonly focuses on the heat storage of the hot walls based on phase change materials. Although both the thermal performance of the hot walls and the thermal environment of the heating houses are demonstrated to be greatly improved, the potential and feasibility of extensive promotion deserve further study. Furthermore, finding more practical solutions to improve the thermal performance of the hot walls may be effective for its applications in rural heating. 
Generally, the hot wall is one of the most effective methods applied for rural heating, which can achieve sustainable development. Research and technological upgrading will provide important social, environmental, and economic values [34].

\subsection{Burning Cave Heating Method}

The burning cave (Figure 1c) is located below the heating room taking biomass as fuel [35]. The heat generated by smoldering biomass continuously radiates into the heating room through the floor layer and the ceiling of the burning cave [36]. Controlling the smoldering combustion of fuel is the key technology for the burning cave heating [37]. The fuel accumulates in the storage channel in a clastic form, and it slowly collapses when it burns, thus it offers relatively continuous room heating during the whole heating season [38]. Moreover, the air volume entering the fuel storage channel can be regulated by controlling the size of the opening size of the damper, therefore the fuel combustion rate and the indoor temperature can be adjusted [38].

The development of the burning cave heating is undergoing an evolution from single mode to coupled mode with other technologies, from the application of specific environmental adaptability to diversification, and from manual control to mechanized intelligent control [37]. Studies [36,37] have shown that by energy cascade utilization, some of the practical problems of the burning cave can be solved, such as centralized heating dissipation, partial overheating, and serious heat loss. Consequently, the thermal energy utilization and heating performance of the burning cave are improved. A hot water heating system based on burning cave was proposed by setting parallel pipes below the ceiling of the burning cave [37]. The arrangement of coils was improved on the basis of optimizing the structure of the burning cave, then the excessive heat inside was utilized for heating through water. Also, it was found that the surface temperature of the floor was uniform and below $30^{\circ} \mathrm{C}$ during the heating period without the phenomenon of partial overheating, and the effect of the coupled heating pattern was superior to that of the single smoldering cave pattern [38].

The burning cave has greater advantages over other traditional heating methods in rural areas. It can provide a satisfying thermal environment for rural residents and make full use of biomass to reduce heating costs. Therefore, the burning cave heating is worth promoting and applying in rural areas [39].

\subsection{Indigenous Water Heating Method}

Indigenous water heating system (IWHS), i.e., natural circulation hot water heating system (Figure 1d) [40], has been commonly utilized in rural China [41]. IWHS can be considered as a miniaturized gravity cycled hot water heating system. The individual boiler filled with water is commonly placed inside a stove, the water is heated, then the heated water flows to each radiator for room heating, and then the water temperature decreases, after that the water flows back to the boiler, and the water is reheated and continue to circulate. As there is a temperature difference between the supply water and the return water, the cyclical power produced by the density difference provides the circulating power [39]. In most practical cases, the IWHS only provides heating for the residents' own house, therefore the heating radius and the total resistance loss are small, as a result, the acting pressure generated by the density difference is usually adequate to provide the circulating power, thus the circulation pumps are not needed. However, some micro circulation pumps are used as auxiliary power if the power provided by system itself is not enough.

In the rural China, household IWHS makes use of the waste heat of cooking to heat the water in the boiler in the stove [42]. At present, the stoves used as the heat source in the IWHS can be divided into: masonry stove/iron stove, heating stove/heating-cooking stove, and coal fired heating stove/biomass gasifier [43]. Since IWHS in rural areas is generally designed and constructed on the basis of experience, it shows the characteristics of low energy efficiency and serious energy waste. In IWHS, the available waste heat of the exhaust smoke is $3024 \mathrm{~kJ}$ for every $1 \mathrm{~kg}$ of bituminous coal burned, accounting for $12.4 \%$ of the low calorific value of the bituminous coal [41]. According to the theory of 
energy cascade utilization, Zhao [41] proposed a tunnel heating method for making full use of the waste heat, which could save $9.17 \%$ of heating energy consumption compared with the original IWHS.

\section{New Rural Heating Methods}

\subsection{Solar Heating Method}

The solar heating system utilizes solar collectors to convert solar energy into heat energy, and then the heating water is supplied to the buildings for room heating and other thermal systems. Figure $2 \mathrm{a}$ shows the schematic diagram of the active solar heating system [44]. The solar heating system is mainly composed of solar collectors, heating pipes, heat dissipation equipments, heat storage equipments, and auxiliary heat sources [45]. And solar thermal utilization is mainly constrained by the low heat utilization efficiency and the intermittent and seasonal effects of sun radiation [46]. Due to the low solar energy density, a larger collection area is required to meet the heating demands. As the building volume rate of the rural houses is generally low, and there is no obvious shelter around these houses, it is suitable for the promotion and application of solar heating technology in rural China [47].

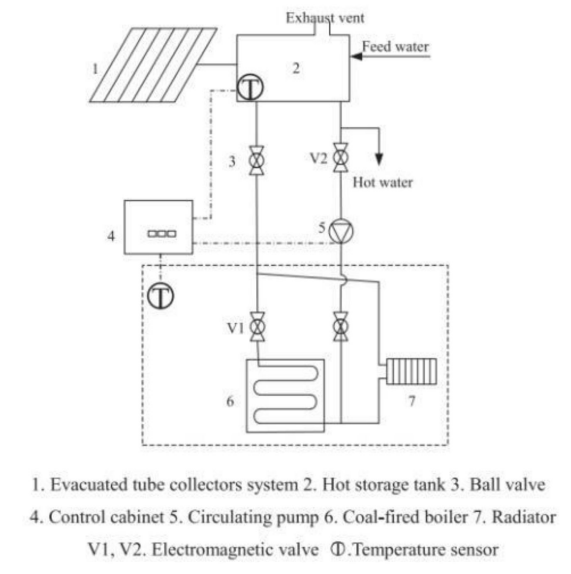

(a) The active solar heating system

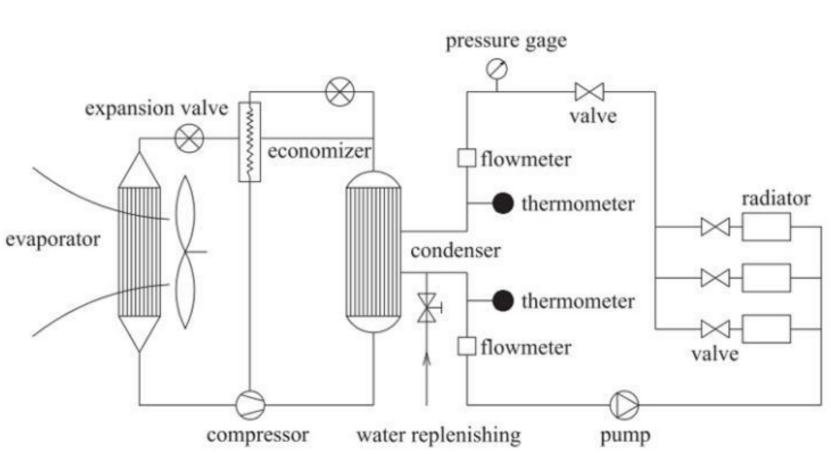

(b) Air source heat pump combined with raditor
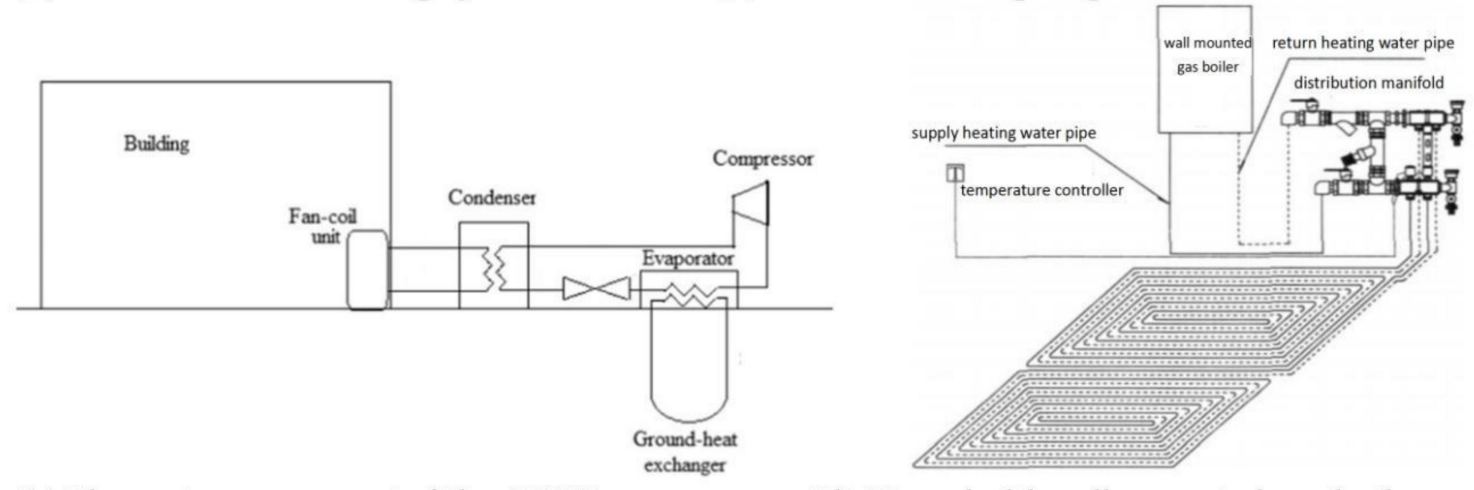

(c) The main component of the GSHP

(d) Household wall-mounted gas boiler

Figure 2. Schematic diagrams of new rural heating methods.

Solar active heating is demonstrated to ensure healthy indoor air quality, comfortable heating temperature, significant energy saving, and environmental protection. An active solar water heating system was extensively researched, which was applied to a new rural residence (experiment residence) insulated with $60 \mathrm{~mm}$ extruded polystyrene, by comparing it with the traditional mini coal-fired boiler for heating in a reference new rural residence (reference residence) without external wall insulation during period in Minqin, Gansu province, China. When the lowest outdoor environment temperature was $-16.2^{\circ} \mathrm{C}$, the average indoor temperature reached $14.5^{\circ} \mathrm{C}$ which was about $5.4^{\circ} \mathrm{C}$ higher than that of the reference residence, and the average relative humidity was $58.0 \%$, which made residents 
feel comfortable indoors in winter [44,47]. Also, one solar active-passive combined heating system provided a stable indoor temperature of $14{ }^{\circ} \mathrm{C}$ or more for single rural buildings with a passive sunlight area of $170 \mathrm{~m}^{2}$ in Gansu Province [48]. In addition, when radiator heating was changed to low-temperature floor heating, heat stored in the hot water can be utilized more than the original radiator's heating, therefore, the days only relying on solar heating increased, the times using coal fired boilers decreased, and the stability of the energy supply was significantly improved. The results showed that this system's solar energy guarantee rate is $60.3 \%$, and $2372.4 \mathrm{~kg}$ of standard coal can be saved, 6.22 tons of carbon dioxide emission can be reduced [49].

Specially, in the case of using the radiator heating, the initial cost of a new rural residence was 150,000 yuan, while the additional cost including the active solar heating system, control cabinet, external wall insulation, labor cost and the other accessories was 21,700 yuan. Moreover, the energy saving fraction of experiment residence was $78.0 \%$ during the heating period, which showed that the experiment residence could save 5032 yuan in winter, therefore, the corresponding static payback period of the additional cost was about 4.4 years [44]. After utilizing a solar active-passive combined heating system, one single rural building with a passive sunlight area of $170 \mathrm{~m}^{2}$ in Gansu Province could reduce the usage of standard coal by 4.3 tons in the heating season, then the dynamic investment payback period was 4.9 years. In addition, the concentrations of $\mathrm{CO}, \mathrm{NO}_{2}, \mathrm{SO}_{2}, \mathrm{CO}_{2}$ and PM10 in the experiment residence mentioned above were respectively $0.45,0.48,0.56,0.59$ and 0.5 times that of the reference residence [47]. Moreover, the indoor thermal environment and the indoor air quality of the heating rooms under solar energy heating are the best compared with Kang heating and household coal-fired boiler radiator heating in three rural houses during two winter heating periods in Gansu Province [50].

\subsection{Heat Pump Heating}

\subsubsection{Air Source Heat Pump Heating Method}

Air source heat pump (ASHP) is a device that takes air as a low temperature heat source and is driven by a small amount of high-grade energy (e.g., electricity) (Figure 2b) [51]. In winter, heat is transferred from the system to the room for heating [52]. Compared with the small-scale coal-fired boiler, the ASHP heating method is more suitable for houses distributed in rural areas with the advantages of a reasonable price, simple system, and easy maintenance [53].

The potential for ASHP technologies as an alternative to solid and liquid fuels was analyzed based on economic analysis, and it is found that ASHP can play an important role in managing residential emissions, reducing household energy costs and relieving healthy impacts [54]. Pang et al. considered the low temperature air source heat pump heating technology as the alternative rural heating method and calculated the environmental benefits, after full promotion, the annual emission reduction of carbon dioxide, sulfur dioxide, nitrogen oxides, and dust in rural China are approximately 386 million, 0.115 billion, 0.057 million, and 105 million tons, respectively [55].

Luo et al. [56] proposed one air source heat pump heating system to replace traditional Kang heating in rural areas of Xi'an, Shanxi Province. The system can effectively raise the indoor temperature to over $14{ }^{\circ} \mathrm{C}$ under the effects of the appropriate working conditions with the supplied water temperature between $35{ }^{\circ} \mathrm{C}$ to $50{ }^{\circ} \mathrm{C}$. Correspondingly, the daily running cost of a heating room is between 1.67 yuan and 4.18 yuan. For the typical rural residence with a heating area of $80 \mathrm{~m}^{2}$ in Beijing, air source heat pump with radiator heating has the lowest annual operating cost of 22.3 yuan $/ \mathrm{m}^{2}$ to reach the required indoor temperature of $14{ }^{\circ} \mathrm{C}$, compared with de-centralized coal stoves heating $\left(59.7 \mathrm{yuan} / \mathrm{m}^{2}\right)$ and briquette stove heating (51.6 yuan $/ \mathrm{m}^{2}$ ) [57]. Zhang conducted research on low temperature air source heat pumps for residential heating applications in Beijing rural areas [58]. The results showed that the low temperature air-to-air heat pump could increase the room temperature instantly, realizing heating with more flexible time and space, which contributed to a great potential for energy savings in comparison with the traditional whole household heating patter. Specially, annual heating costs can be reduced to 13 yuan $/ \mathrm{m}^{2}$ in behavioral energy saving mode (i.e., part time and part space), which is significantly 
lower than that of coal heating ( 39 yuan $/ \mathrm{m}^{2}$ ) and that of air-to-water heat pump with floor radiant heating $\left(28\right.$ yuan $\left./ \mathrm{m}^{2}\right)$, respectively.

Moreover, the ASHP can be well combined with floor radiant heating system [59]. After field measurement of the direct floor radiant heating system using the refrigerant as the heating medium in Zhengzhou, Henan Province, it was found that under the experimental condition of outdoor air temperature of $3.1^{\circ} \mathrm{C}$ and humidity of $26-32 \%$, the ASHP operated in a stable condition, the surface temperature of the floor reached $26{ }^{\circ} \mathrm{C}$ and the room temperature was $22{ }^{\circ} \mathrm{C}$, which fully met the requirements of indoor heating [60]. In Changsha, Hunan Province, when the outdoor temperature ranged between $4-14{ }^{\circ} \mathrm{C}$, the indoor air temperature provided by an ASHP floor heating system was basically in the range of $16-20^{\circ} \mathrm{C}$ [61].

It is indicated that the total investment of the low temperature ASHP heating scheme is relatively low, and primary energy efficiency significantly increases, therefore the coal consumption, the emissions of pollutants and toxic substances can be significantly reduced [62]. It can be considered as the preferred option to upgrade the traditional heating methods in rural China [55]. However, there are also some deficiencies in this system, such as noise problems caused by compressors and fans of the unit, heating efficiency reduction due to lower ambient temperatures and unit defrosting, etc [63]. In order to support more reliable and stable heating, more research should be conducted to provide technical support.

\subsubsection{Ground Source Heat Pump Heating Method}

Ground source heat pump (GSHP) system is a heat pump air conditioning system, which consumes a small amount of high-grade energy (e.g., electricity) to realize the transfer from shallow geothermal energy (e.g., soil heat energy, low grade thermal energy in groundwater or surface water) to high grade thermal energy. According to the source of shallow geothermal energy, it can be divided into three types: surface water source heat pump system, groundwater source heat pump system and soil source heat pump system [64]. As shown in Figure 2c [65], during the heating season, the earth serves as a low temperature heat source for the heat pump unit, and heat is collected from the soil via the buried coils for room heating $[66,67]$.

Compared with ASHP, the GSHP is less affected by the climate, which provides a possibility for its rapid development in rural China [52]. However, due to the influence of water recharging and water quality, the maintenance of the water source heat pump is difficult, and the service life is highly uncertain. In contrast, the soil source heat pump operates stably, requires little maintenance, and has a long service life of up to 50 to 70 years [68]. Therefore, buried tube GSHP is very suitable for widespread promotion in rural China [52]. In Beijing, a three storey villa with an area of $400 \mathrm{~m}^{2}$ was transformed from gas fired heating to GSHP heating. It was demonstrated that the indoor temperature was generally maintained at about $20{ }^{\circ} \mathrm{C}$, and the unit could operate without failure during the test period after tracking the actual operating status of the system. Meanwhile, this GSHP air conditioning heating system consumed about 8000 yuan for electricity during a heating season (120 days), equivalent to about 20 yuan $/ \mathrm{m}^{2}$, which was a significant savings over the previous year's gas cost of 16,000 yuan. Therefore, it indicates that this technology is economical and energy-saving [69]. However, spatial and economic constraints exclude $7.7 \%$ and $89 \%$ of homes respectively, leaving only $10 \%$ of homes suitable for retrofit, but the percentage of GSHP-suitable homes would increase from $10 \%$ to $30 \%$ with a $30 \%$ federal tax credit while reducing the average payback period from 9.1 to 4.8 years among those homes [70].

GSHP shows the characteristics of being energy saving, environmentally friendly, stable in operation, and capable of being used for multiple purposes [71]. If it operates at a relatively low temperature, a high efficiency solution can be obtained for the heating of buildings, and its coefficient of performance (COP) is usually in the range of 3 to 3.8 [65]. However, in practical applications, the GSHP will be limited by some conditions, such as the available water source conditions, the geological structure of the water layer, the large initial investment, and the long payback period [68]. In order to ensure the long-term stable operation of the GSHP, factors such as the regional climate and geographical 
conditions and the building load differences should be taken into consideration before installing GSHP systems.

\subsection{Gas Heating Method}

Gas heating includes three main methods: household wall mounted gas boiler (HWMGB) heating, small gas boilers independent heating and large gas boiler centralized heating [72]. Figure $2 \mathrm{~d}$ shows the diagram of the household wall mounted gas boiler [73]. Considering the factors of safety, economy, energy saving and emission reduction, the household wall mounted gas boiler heating is the optimal method for rural heating among the gas heating methods [74].

HWMGB heating can supply heating sources and domestic hot water separately for villas or apartment houses [73,75]. As shown in Figure 2d, water is heated by the firing of the gas, the circulating water pump sends the hot water to the radiator or floor heating coil for room heating, then the water is returned to boiler $[73,76]$. The radiating facility for a HWMGB heating system can be common radiators or low temperature floor with high thermal comfort [73]. HWMGB heating systems have many advantages, such as low costs, energy saving, easy installation and operation, high thermal comfort, and space saving [77]. However, some shortcomings cannot be neglected, such as a short service life, a certain potential of safety hazard, a certain impact on air quality, and certain expenses for maintenance and equipment depreciation [77]. Generally, the HWMGB heating is a suitable substitute for rural heating considering the flexible heating periods and the personalized demand heating temperatures of rural residents.

Obviously, the core issue of this heating method is the supply of gas. A stable and adequate gas supply is a significant guarantee for the residents' heating, especially during continuously cold days. Moreover, the residents lived in rural areas far from the cities can hardly consider the HWMGB heating as an option due to the lack of a gas supply network. Hence, gas supply is a prerequisite for this heating method.

\section{Coupled Heating Method}

\subsection{Definition of Coupled Heating Method}

According to the above analysis, it is found that the single heating method has certain limitations. Studies have shown that the utilization and optimization of scientific coupled systems can overcome those disadvantages, improve the overall energy efficiency of the system, and maintain the stability and durability of heating [78]. Coupled heating systems consist of two or three types of energy utilization, e.g., a combination of solar or/and heat pump or/and coal fired boiler, a combination of solar and heat pump, etc. For these coupled systems, a relatively stable heating source is adopted to ensure the stability of heating, and a relatively unstable heating source is adopted to supply heat according to the maximization of its own conditions, as a result, the system can get maximum thermal feedback by paying minimum cost.

\subsection{Influencing Factors}

The coupled systems are affected by multiple factors, including the water tank volume, the collector area, the radiant intensity, the operating mode of the system, the combination of the subsystems, the borehole depth, the heat pump refrigerant, and the electricity price $[79,80]$. Ozgener and Hepbasli [81] indicated that regardless of whether the solar energy was stored in tanks or in the earth, the period of using the stored heat directly affected the performance of the coupled system [80]. Liang et al. [82] established a novel solar assisted air source heat pump system and proposed three operating strategies. When the available solar radiant heat was less than or equal to the heat dissipation of the solar collectors, the utilization of solar thermal heating was stopped. The results showed that the solar radiation intensity and the solar collector area were the main factors influencing the performance of the system. Emmi et al. [79] adopted a reasonable operation strategy for a solar 
assisted ground source heat pump system to maximize heat pump thermal efficiency. Also, it was found that the total depth of borehole of GSHP could be effectively reduced after the combination of solar energy. When the total length reduced to half of the initial value, the performance of the heat pump was not affected to any degree. Bellos and Tzivanidis [83] selected 20 European cities to test the same coupled system in buildings with the same architectural features. It was concluded that the total cost of coupled systems in most cities was lower than that of a single ASHP system. Moreover, for buildings with a good envelope, the coupled system had a short payback period. It was also suggested that the area of the collector should be scientifically chosen to be as small as possible.

\subsection{Specific Application Forms}

\subsubsection{Solar Coupled Heat Pump}

Extensive attention and research has been focused on solar coupled heat pump heating systems. As shown in Figure 3 [84], solar can takes effects on the evaporation side and the condensation side [85], it can also be directly used for heating or stored in a water tank [83] and in the soil [79]. Therefore, the coupled system can provide a stable, sustainable and comfortable indoor thermal environment.

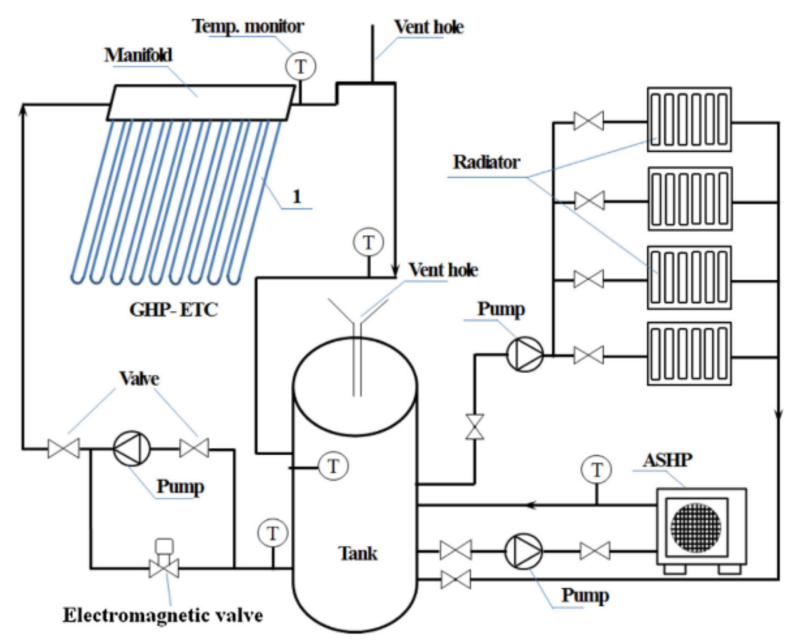

Figure 3. Schematic diagram of an integrated space heating system.

For the solar coupled heat pump systems, a continuous 96-day test of an ASHP assisted solar heating system for a rural house in Beijing indicated that under the premise that solar heat collection was limited by weather conditions, heat supply can be increased through auxiliary energy sources , then when the average daily outdoor temperature was $1.0^{\circ} \mathrm{C}$, the daily average indoor temperature was $19.6^{\circ} \mathrm{C}$, the daily average COP of the ASHP unit was 4.29 , and the daily average comprehensive energy efficiency ratio of the heating system was 3.52 [86]. The integrated system including passive sunspace, active solar water heating, and ASHP showed many encouraging results in terms of the maintenance of a stable and comfortable indoor thermal environment during the winter season in a cold climate zone, which was suggested as a promising future technology for energy savings and emission reductions in rural buildings [87]. Taking the example of a 2-floor radiant floor heating house $\left(300 \mathrm{~m}^{2}\right.$ living area and 6 persons) in Xi'an, three heating methods (solar system, ASHP, and electric heater) were used to heat the system's water according to the climate and load characteristics. Compared with traditional coal fired boilers, the coupled system can reduce carbon dioxide emissions by $4810.1 \mathrm{~kg}$ and save an annual operating cost of 3174 yuan during the whole year's operation. However, the initial investment of the coupled system was about 28,000 yuan, thus the economic performance of the coupled system should be further studied $[87,88]$. 
For the combined system of soil source heat pump and solar inter-seasonal heat storage, the thermal response process of the soil is influenced by the alternating heat effects of the solar energy and the heat pump [89,90]. The simulation results showed that the soil thermal radius was about $2.5 \mathrm{~m}$. Also, the soil temperature outside the radius fluctuated little throughout the whole year. Moreover, the soil heat transfer was faster in the radial direction and slower in the depth direction. When the ratio of heat flow in summer, autumn, winter and spring was 4.5:1:-4:0, the soil temperature had almost completely recovered. In addition, under the premise that the ratio of soil heat storage and heat release remained unchanged, the changes in the heat exchange rate between the borehole and the soil had little effect on the soil temperature recovery rate [90]. After studying on the performance of a solar-ground tube heat pump combined system used in a $220 \mathrm{~m}^{2}$ villa in Beijing, the results indicated that the soil temperature increased by $3{ }^{\circ} \mathrm{C}$ and the capacity of the heating unit increased by $8 \%$ [91]. During the entire heating season (about 5 months), the COP of a solar assisted soil source heat pump heating unit in Tianjin was 3.98, while the average COP of the heat pump system was 4.33 . It can be concluded that the performance of this coupled system was better than that of any independent system. Compared with common GSHP, the COP of the coupled system could increase by 0.3 , and it could save about $2100 \mathrm{kWh}$ in winter [92]. Generally, the solar assisted ground source heat pump can effectively improve the COP of the heat pump, prevent the occurrence of frozen soil and accelerate the recovery of the underground temperature field, achieving long term stable and efficient heat pump operation [78].

\subsubsection{Solar Coupled Kang}

With the continuous development of solar energy utilization, the adaptability and application of solar heating have been improved. For a novel solar energy heating system combining the solar thermal storage tank and the traditional Kang, the thermal storage tank without thermal insulation heats the room by natural heat dissipation, and the setting of the flue under the thermal storage tank can also make full use of the waste heat of the smoke [93]. Zhao et al. [94] explored the practicability of a hybrid solar heating system combining a solar Kang subsystem and a solar air heating subsystem in rural buildings in Qinghai Province by field measurement and simulation. The results indicated that the indoor temperature of the test room can be improved by up to $6{ }^{\circ} \mathrm{C}$ when the ambient temperature was $7.8^{\circ} \mathrm{C}$ (average), moreover, the area of collectors, thermal insulation, and an appropriate operation strategy were important factors. Specially, the Kang surface average temperature can be improved from $22{ }^{\circ} \mathrm{C}$ to $31^{\circ} \mathrm{C}$ by changing the solar collector area from $4 \mathrm{~m}^{2}$ to $8 \mathrm{~m}^{2}$. Also, the thermal load of sleeping can be also kept within acceptable levels when the bedding's insulation value was maintained at 4.0 clo $\left(1.0\right.$ clo is equivalent to $\left.0.155\left(\mathrm{~m}^{2} \cdot \mathrm{K}\right) / \mathrm{W}\right)$ during night time.

Although the Kang directly using the solar energy can solve indoor and outdoor pollution problems, its drawback in a slow rise of indoor temperature cannot be overcome due to its large heat capacity [95]. Wei et al. [95] developed a novel combined solar Kang system consisting of a solar air collector which provided passive heating and a solar Kang system which provided active heating. After field measurement, it was found that when the system was running in the evening mode, the total time that the temperature of Kang and indoor air maintained at above $18^{\circ} \mathrm{C}$ was $43.3 \mathrm{~h}$ and $10.6 \mathrm{~h}$, respectively. Considering the fact that the use of solar energy is easily affected by weather conditions, the phase change heat storage materials and their microencapsulation can be utilized, thus solar energy can be utilized more efficiently [46]. Guo et al. [96] conducted preliminary analyses on the performance of solar phase change materials, and found that if the surface temperature of the Kang was the same as the solidification temperature of the phase change material during the heating period, then the nighttime sleep quality was improved to some extent.

Generally, this novel coupled heating system provides a new idea for the use of traditional heating methods. After reasonable design, the solar coupled Kang heating method can meet the rural residents' thermal requirements, especially in regards to sleep comfort. 


\section{Discussion}

\subsection{Application of Different Heating Methods}

According to the above reviews on the technical characteristics, thermal comfort, environmental protection, and economic characteristics of most existing heating methods and some new heating methods, it is indicated that the traditional heating methods, such as Kang and stove [8,9,97], are still widely used due to their historical characteristics and their advantages of simple construction, convenient use, and low investment. However, those new heating methods have not been effectively promoted in rural areas as a result of the following reasons: being vulnerable to natural disturbances such as weather and soil thermal properties, complex structures, and expensive initial investment beyond the acceptable range of rural residents [10]. Despite that, these new heating methods, e.g., solar heating and ASHP heating, should be promoted due to their significant benefits on carbon emission reduction, national energy structure optimization and improvement of rural residents' thermal environment. In addition, the coupled heating methods should be proposed and studied, which provide novel solutions for rural heating.

\subsection{Factors Influencing New Heating Methods Selection}

The selection of rural residential heating methods is influenced by many factors, it is significant to study the influencing factors while promoting the new rural heating methods. The statistically significant factors affecting residential heating system selection mainly include: socioeconomic characteristics (e.g., income, age, educational level, etc.), residence characteristics (e.g., residence size, type of residence, year of construction, etc.), spatial characteristics (e.g., region, area type, climate, etc.), consumers' behavior and attitudes, and system attributes preferences ( e.g., economic aspects, environmental considerations and energy saving, comfort considerations and aesthetics, social reasons and information/knowledge aspects, etc.) [98]. Spatial and economic constraints highly affect the adoption of new heating methods, especially the economic constraints [70]. The high initial cost is a main diffusion barrier of the new heating methods. Moreover, income, science literacy, local environmental concerns, educational level, and awareness of renewable energy systems and alternative technologies positively affect residents' willingness to adopt (WTA) and willingness to pay (WTP), whereas global environmental concerns do not $[99,100]$.

To promote the utilization of the new heating methods, firstly, appropriate financial subsidies are suggested to reduce the rural residents' initial investment, moreover, the relative policy support during the systems' operation are essential for sustainable utilization in rural heating. Secondly, field investigations considering the differences in residents' living habits and energy endowments in different rural areas are necessarily conducted before promoting new heating methods or upgrading existing heating methods. Thirdly, more information about heating methods should be provided to address concerns about new heating methods, and misunderstandings about the original heating methods. It is encouraged to make the operation strategy control more intelligent and simplified, then the new heating methods would be more easily acceptable. Fourthly, the local environment concern and local natural resources (e.g., the gas network, local solar energy) should be paid more attention, which may positively affect the promotion of new heating methods.

\subsection{Rural Heating Method Solutions}

\subsubsection{Residential Demand Analysis}

Long-term climate adaptation requires a wider range of acceptable thermal comfort temperatures [101]. It is necessary to study rural residents' special heating demands while promoting new heating methods or upgrading existing heating methods in order to achieve the dual targets of energy conservation and indoor thermal environment improvement. It is indicated that, in rural houses, the temperature of the master room can be set to $13^{\circ} \mathrm{C}$, while the temperature of the auxiliary 
rooms (e.g., the secondary bedroom, the kitchen and dining room, etc.) can be set to $11^{\circ} \mathrm{C}$ [102]. In addition, the heating pattern of part time and part space is required in rural residences. To some extent, bed warming may be effective and suitable [94].

\subsubsection{Solutions on Heating Methods}

In recent years, scholars have conducted in-depth research and provided optimization suggestions on the aforementioned traditional heating methods. After optimization and reconstruction, these heating methods all show great application performances. Compared with installing a new system, upgrading based on the original heating system can greatly reduce the costs for new equipment, showing good economic benefits. Moreover, the heating methods of the Kang, the hot wall and the burning cave show great Chinese wisdom in space heating with rational use of space. It is suggested that the Kang, the hot wall and the existing radiators can be adopted as the heating terminals of the upgraded systems. Ways to further improve the traditional heating methods still need to be studied and explored. Scientific basis and relative standards for design and construction are also suggested for the promotion of their application.

The new heating methods mentioned above show great benefits for thermal comfort, environmental protection, and operational economy. Obviously, new heating methods can mostly satisfy rural residents' heating demands. However, some inherent characteristics of the new rural heating methods limit their promotion, e.g., the frosting problem of ASHPs, problems of the heating source stability for GSHPs, sensitivity to weather conditions of solar heating, and the problem of rural gas supply for gas heating. The limits of the new rural heating methods deserve further research.

The coupled heating systems are proposed and studied, which provide more choices for rural heating solutions. Proper passive design measures should be taken into account for their positive effects on thermal comfort and energy conservation [103]. As a result of these measures, the residence can extend the non-heating period, which may positively affect the systems' performance, e.g., the utilization of passive solar house technologies, the bedding's insulation, etc. At present, although there are many schemes for combined systems and operational strategies for coupled systems, there is no consensus on the optimal solutions. Moreover, there are gaps in the study of the sustainability and adaptability of the same coupled system in different typical meteorological cities in China. Therefore, there is no specific reference for choosing combined systems schemes and operational strategies.

\section{Conclusions}

Current high heating demands in rural China cannot be satisfied, while the process of upgrading the existing heating methods into more environmental friendly heating methods is facing challenges. It is difficult to select the appropriate heating method for new and existing residences. Due to the huge housing areas in rural China, proper heating methods are essential to adopt to avoid huge energy waste and pollutant emissions. Therefore, it is significant to review rural heating methods in order to provide scientific and practical references.

In the short term, traditional heating methods will still be the main heating methods of most rural residents, despite their many existing deficiencies. Solutions are proved to be practical and effective to improve thermal performance, e.g., the optimization and reform of the original systems, the utilization of clean energy and heat storage materials, and the use of less polluting fuel, etc. The use of burning cave for heating can effectively use rural biomass and other abandoned available energy sources. After scientific transformations, burning cave heating has achieved improvements regarding both thermal comfort and environment protection. In general, the traditional heating methods can still be used for rural heating during the transition period.

New heating methods based on clean energy have the characteristics of good environmental benefits, high thermal comfort and low operating costs. However, the effective promotion of new heating methods is highly affected by spatial and economic constraints and other factors, which should be further investigated. Also, providing policy assistance (e.g., appropriate financial subsidies) 
is encouraged and essential. Considering the national sustainable development requirements, new heating methods deserve further promotion.

Coupled heating systems can effectively compensate for the deficiencies of the single heating method, and the solar coupled systems are mostly proposed and studied. The solar coupled Kang heating systems are suggested to upgrade the rural residence with Kang. It is also encouraged to integrate the solar passive technologies with coupled heating methods in rural heating. In addition, it is necessary to develop intelligent control systems to simplify the operation of coupled systems. Generally, coupled heating methods have great potential for future application.

Author Contributions: Conceptualization, G.Z.; formal analysis, W.B.; investigation, W.B.; resources G.Z. and W.B.; writing-original draft preparation, W.B.; writing—review and editing, G.Z.

Funding: This research was funded by "the Fundamental Research Funds for the Central Universities, Grant No. 2018MS110".

Conflicts of Interest: The authors declare that they have no competing interests.

\section{References}

1. He, B.J.; Yang, L.; Ye, M.; Mou, B.; Zhou, Y.N. Overview of rural building energy efficiency in China. Energy Policy 2014, 69, 385-396. [CrossRef]

2. Kerimray, A.; Rojas-Solórzano, L.; Torkmahalleh, M.A.; Hopke, P.K.; Gallachóir, B.P.Ó. Coal use for residential heating: Patterns, health implications and lessons learned. Energy Sustain. Dev. 2017, 40, 19-30. [CrossRef]

3. Huo, M.L.; Zhao, J.; Xu, C.; Shan, B.G.; Jia, D.X. China scattered coal consumption map and influence factors. Electr. Power. 2017, 50, 1-8. (In Chinese)

4. Sun, Z.; Huang, X.; Liu, J.L. Application status of heating and air conditioners in rural residences of China. Hous. Sci. 2013, 33, 53-56. (In Chinese)

5. Sun, R.J.; Lü, J.; Ren, S.F.; Wang, L.W. Investigation on energy consumption of rural residential housing in northeast area. Build. Energy Environ. 2011, 30, 45-48. (In Chinese)

6. Enshen, L. Are the relative variation rates (RVRs) approximate in different cities with the same increase of shape coefficient? Build. Environ. 2005, 40, 473-480. [CrossRef]

7. Depecker, P.; Menezo, C.; Virgone, J.; Lepers, S. Design of buildings shape and energetic consumption. Build. Environ. 2001, 36, 627-635. [CrossRef]

8. Zhen, M.; Sun, Ch.; Dong, Q. Investigation on Energy Consumption in Rural Residential Buildings During Heating Season in Severe Cold Areas in Northeast of China. Procedia Eng. 2016, 169, 19-25. [CrossRef]

9. Zhao, Y.; DuanMu, L.; Wang, Z.S.; Zhu, J.L.; Shan, H.N.; Shu, H.W. Experimental study on thermal performance of hot wall type Kang. Build. Sci. 2010, 26, 29-36. (In Chinese)

10. $\mathrm{Xu}, \mathrm{J} . ; \mathrm{Gao}, \mathrm{W} . \mathrm{J} ;$; Huo, X.P. Analysis on energy consumption of rural building based on survey in northern China. Energy Sustain. Dev. 2018, 47, 34-38. [CrossRef]

11. Guo, C.C.; Guo, M.S.; Pan, X. Application analysis of biomass fuel in rural hot water heating. Energy Conserv. 2014, 33, 68-70. (In Chinese)

12. Wang, R.; Jiang, Z.J. Energy consumption in China's rural areas, A study based on the village energy survey. J. Clean. Prod. 2017, 143, 452-461. [CrossRef]

13. Liu, J.; Zou, Y.; Song, B. Application status and optimal design of indigenous water heating system to the northern rural housing. Heat Vent. Air Cond. 2013, 43, 25-29. (In Chinese)

14. Yao, Ch.Sh.; Chen, Ch.Y.; Li, M. Analysis of rural residential energy consumption and corresponding carbon emissions in China. Energy Policy 2012, 41, 445-450. [CrossRef]

15. Fan, J.L.; Liao, H.; Liang, Q.M.; Tatano, H.; Liu, C.F.; Wei, Y.M. Residential carbon emission evolutions in urban-rural divided China: An end-use and behavior analysis. Appl. Energy 2013, 101, 323-332. [CrossRef]

16. Zhi, G.R.; Yang, J.C.; Zhang, T.; Guan, J.; Du, J.H.; Xue, Z.G.; Meng, F. Rural household coal use survey, emission estimation and policy implications. Res. Environ. Sci. 2015, 28, 1179-1185. (In Chinese)

17. Shan, M.; Wang, P.S.; Li, X.D.; Yang, X.D.; Yang, M. Investigation and analysis of the current situation of rural residential energy consumption in China. Build. Sci. 2012, 28, 14-19. (In Chinese)

18. Su, C.; Madani, H.; Palm, B. Building heating solutions in China: A spatial techno-economic and environmental analysis. Energy Convers. Manag. 2019, 179, 201-218. [CrossRef] 
19. Zhuang, Zh.; Li, Y.G.; Chen, B.; Guo, J.Y. Chinese kang as a domestic heating system in rural northern China-A review. Energy Build. 2009, 41, 111-119. [CrossRef]

20. Gao, X.X.; Hu, R.R.; Liu, J.P.; Tang, F.W. Research on winter indoor thermal environment of courtyard house with Chinese Kang in the North China. Build. Sci. 2010, 26, 37-40. (In Chinese)

21. Zhang, P.H.; Xia, F.L.; Fu, J.Y. The analysis and numerical simulation of factors of the influence on heating Kang. J. Shenyang Jianzhu Univ. (Nat. Sci.) 2009, 25, 342-346. (In Chinese)

22. Sun, S.J.; Zhao, Y.D. Exploring the new road for the sustainable development of Kang residence in the Cold Regions. Low Temp. Archit. Technol. 2005, 26, 90-91. (In Chinese)

23. She, C.M.; Li, G.; Guo, J.T.; Wang, L.Z.; Yu, X. Analysis of application of Kang in heating in rural China and energy-saving reform measures. Doors Windows 2016, 47, 7. (In Chinese)

24. Xu, D.; Wang, X.Y.; Pei, Y.P. Analysis of the Kang and burning cave in rural dwellings in Liaoning province. Sichuan Build. Sci. 2010, 36, 299-301. (In Chinese)

25. Zhao, Y.; Zhu, J.L.; Wang, Z.S.; DuanMu, L.; Shu, H.W. Study and analysis of structure and characteristics of comfortable and energy-saving hot wall Kang. China Hous. Facil. 2009, 11, 60-64. (In Chinese)

26. Zhao, Y.; DuanMu, L.; Wang, Z.S.; Zhu, J.L. Experimental study on heat transfer and internal smoke flow of hot-wall Kang. Build Sci. 2010, 26, 17-26. (In Chinese)

27. Ren, H.G.; Li, G.W.; Fang, X.M. Study on the integration of Kang and ventilation for the residential buildings in the cold region. Low Temp. Archit. Technol. 2009, 31, 96-98. (In Chinese)

28. Zhao, X.P.; Zhang, P.; Zhou, T.G. Influences of hot-wall on rural residential thermal environment in severe cold areas. Build. Energy Effic. 2016, 44, 1-5. (In Chinese)

29. Li, G.W.; Zhao, B.; Hao, Y.S.; Xu, C.Z. Study on the reality investigation and countermeasures of rural hot wall. Low Temp. Archit. Technol. 2011, 33, 103-104.

30. Wang, L.R.; Hu, X.T. Research on design of phase change thermal storage device in hot wall in cold villages. Low Temp. Archit. Technol. 2016, 38, 144-146. (In Chinese)

31. Wu, Y.T.; Wang, W.J.; Qi, D.W. Experimental study on application of hot wall with heating water system in North rural area. Bull. Sci. Technol. 2015, 31, 146-149. (In Chinese) [CrossRef]

32. Gao, X.J.; Lian, J.F.; Li, S.X. Exothermic and endothermic process of encapsulation box of phase change material under hot wall condition. J. Build. Mater. 2016, 19, 556-560. (In Chinese)

33. Gao, X.J.; Li, S.X.; Lian, J.F. Heat transfer improvement of macro encapsulation box of organic phase change material under hot wall environment. J. Harbin Inst. Technol. 2016, 48, 138-142. (In Chinese)

34. Han, Y.; Zhang, X.Y. Simulated and comparative analysis on different heating methods in rural residents. Build. Energy Effic. 2010, 38, 67-69. (In Chinese)

35. Zhang, X.Y.; Chen, B.; Zhao, J.R.; Li, X.; Liu, S.; Wu, L.H. Optimization of thermal performance in a Chinese traditional heating system-Burning cave. Energy Build. 2014, 68, 423-431. [CrossRef]

36. Zhang, X.Y.; Chen, B.; Tian, W.Z. Experimental investigation on the hot-water heating system based on burning cave. Acta Energ. Sol. Sin. 2013, 34, 1667-1672. (In Chinese)

37. Zhang, B.G.; Du, G.W.; Liu, M.; Yuan, P.L.; Fan, X.Y. Experimental study of rural winter heating system based on smoldering cave hot-water coil heating. Archit. Technol. 2015, 46, 987-992. (In Chinese)

38. Su, D.L.; Ren, S.Y. Low energy consumption houses in the countryside of Northern China. Renew. Energy Resour. 2007, 25, 77-79. (In Chinese)

39. Li, S.H.; Dong, L.J.; Liu, Sh.Sh. Research status and feasibility analysis of heating in the burning cave. Agric. Technol. 2016, 36, 46-47. (In Chinese) [CrossRef]

40. Wang, J.B.; Liu, Zh.L.; Wang, H.X.; Diao, N.R. The application analysis of coal-fired heating stove in rural areas. Energy Conserv. 2014, 33, 67-74. (In Chinese) [CrossRef]

41. Zhao, Y.B. Research on Tunnel-Type Heating System Using Fuel Gas Heat in Northernrural House. Master's Thesis, Harbin Institute of Technology, Harbin, China, 2014. (In Chinese)

42. Gao, X.X. Research on Traditional Ways of Heating and Indoor Thermal Environment in Rural Areas in North China. Master's Thesis, Xi'an University of Architecture and Technology, Xi'an, China, 2010. (In Chinese)

43. Liu, W.L.; Spaargaren, G.; Heerink, N.; Moi, A.P.J.; Wang, C. Energy consumption practices of rural households in north China: Basic characteristics and potential for low carbon development. Energy Policy 2013, 55, 128-138. [CrossRef] 
44. Li, J.P.; Li, X.Z.; Wang, N.; Hu, Y.Y.; Feng, R. Experimental research on indoor thermal environment of new rural residence with active solar water heating system and external wall insulation. Appl. Therm. Eng.2016, 95, 35-41. [CrossRef]

45. Gao, X.Y.; Fan, B.Y.; Zhang, H.G. Study on Application of solar heating system in new countryside construction. Acta Energ. Sol. Sin. 2009, 30, 1653-1657. (In Chinese)

46. Yang, L.Q.; Wang, Q.; Liu, S.S. Application and Development of Solar Heating System. Agric. Technol. 2016, 36, 169-171. (In Chinese)

47. Li, J.P.; Zhen, X.F.; Li, X.Z.; Cui, W.D.; Dong, T. Experimental study on indoor thermal environment of active solar heating in new rural residential construction. J. Chin. Agric. Mech. 2016, 37, 161-165. (In Chinese)

48. Li, J.P.; Wang, H.; Wang, Z.F.; Huang, J.J.; Wang, C.L. Performance of solar active-passive combined heating system in Tibetan areas of southern Gansu. Trans. Chin. Soc. Agric. Eng. 2018, 34, 1-7, (In Chinese with English Abstract). [CrossRef]

49. Li, J.P.; Si, Z.T.; Kong, Y.; Wang, L.; Zhen, X.F. Experiment on active solar heating effect for monomer building in northwest region. Trans. Chin. Soc. Agric. Eng. 2016, 32, 217-222, (In Chinese with English Abstract). [CrossRef]

50. Wen, X.B.; Guan, W.J.; Li, H.B. Influence of heating modes on indoor environment of rural residence. J. Chin. Agric. Mech. 2018, 39, 63-70. (In Chinese) [CrossRef]

51. Zhang, Q.L.; Zhang, L.; Nie, J.Zh.; Li, Y.L. Techno-economic analysis of air source heat pump applied for space heating in northern China. Appl. Energy 2017, 207, 533-542. [CrossRef]

52. Cai, Y.; Zhang, D.D.; Liu, D.; Zhao, F.Y.; Wang, H.Q. Air source thermoelectric heat pump for simultaneous cold air delivery and hot water supply: Full modeling and performance evaluation. Renew. Energy 2019, 130, 968-981. [CrossRef]

53. Zhao, W.Y.; Liu, Z.Q. Heating systems and energy-saving technical analysis of rural areas in cold region of China. Build. Energy Effic. 2017, 45, 14-19. (In Chinese)

54. Kelly, J.A.; Fu, M.J.; Clinch, P. Residential home heating: The potential for air source heat pump technologies as an alternative to solid and liquid fuels. Energy Policy 2016, 98, 431-442. [CrossRef]

55. Pang, W.K.; Lü, L.H.; Luo, H. Heating by air-source heat pump for cold climate in Chinese rural regions. J. Environ. Eng. Technol. 2017, 7, 382-387. (In Chinese)

56. Luo, X.L.; Li, J.; Zhu, X.Y.; Wen, H.; Zhao, M. Experimental investigation on contacting heating system assisted by air source heat pump in residential buildings. Energy Procedia 2018, 152, 935-940. [CrossRef]

57. Yu, T.; Qiao, C.Z.; Zhao, Y.Q. Comprehensive analysis of low temperature space heating system with air source heat pump and radiators in rural areas of Beijing. Energy Conserv. 2014, 33, 51-54. (In Chinese)

58. Zhang, L. Research on Low Temperature Air-Source Heat Pump for Residential Heating Applications in Rural Area, Beijing. Master's Thesis, Tsinghua University, Beijing, China, 2015. (In Chinese)

59. Hu, F.C.; Hu, W.J.; Li, D.Y.; Zhang, S. Simulation and Analysis of Air Source Heat Pump Used in Different Heating Terminal of Beijing Rural House. Procedia Eng. 2017, 205, 397-404. [CrossRef]

60. Zeng, Z.C.; Wu, J.J.; Wei, X.L. Experimental Research and thermodynamics analysis of direct radiant floor heating system with air source heat pump. Acta Energ. Sol. Sin. 2011, 32, 1151-1157. (In Chinese)

61. Li, X.Z.; Wang, H.Q.; Zhang, J. Experimental analysis on floor heating system with air source heat pump in Changsha area. Refrig. Air Cond. 2007, 7, 71-75. (In Chinese)

62. Xu, G.; Wang, C.L.; Xu, C.; Bai, P. Evaluation of air pollutant emissions from scattered coal burning and electric heating in Beijing-Tianjin-Hebei region. Res. Environ. Sci. 2016, 29, 1735-1742. (In Chinese)

63. Yu, L.H.; Ma, G.Y.; Xu, R.B. Current status and development of low temperature air source heat pump. Build. Energy Effic. 2007, 35, 54-57. (In Chinese)

64. Wu, T.; Liu, Y.Y.; Dong, Z.; Fang, Y.; Liu, Y.C. Research and application status of ground source heat pump. Chin. J. Refrig. Technol. 2014, 34, 71-75. (In Chinese)

65. Lucia, U.; Simonetti, M.; Chiesa, G.; Grisoli, G. Ground-source pump system for heating and cooling: Review and thermodynamic approach. Renew. Sustain. Energy Rev. 2017, 70, 867-874. [CrossRef]

66. Chen, H.Y.; Yin, K.; Zhuang, Y.C. The development of the geothermal heat pump technology. World Geol. 2002, 21, 203-207. (In Chinese)

67. Diao, Y.; Zhang, X.L.; Wu, Y.W. Advantages and prospects of ground-source heat pump. Energy Res. Inf. 2002, 18, 33-37. (In Chinese) 
68. Liu, Z.H. Comparison between water source heat pump and ground source heat pump. China Constr. Heat. Refrig. 2006, 7, 15-18. (In Chinese)

69. Liu, J.L.; Wang, X.C. Spread and Applications of Ground Source Heat Pump System in Beijing District. Sci.Technol. Inf. 2007, 337-338. (In Chinese)

70. Lim, T.H.; De Kleine, R.D.; Keoleian, G.A. Energy use and carbon reduction potentials from residential ground source heat pumps considering spatial and economic barriers. Energy Build. 2016, 128, $287-304$. [CrossRef]

71. Liu, D.S.; Sun, Y.H. A new technology by using low-ground heat-ground source heat pump technology. Geotech. Eng. Tech. 2003, 17, 57-59. (In Chinese)

72. Zhao, L.Ch. The Study of Natural Gas User Load and Use Rule. Master's Thesis, Beijing University of Civil Engineering and Architecture, Beijing, China, 2016. (In Chinese)

73. Chen, Y.; Zhang, Y.; Zhang, H. Application status and problems of gas wall heater. J. Shanghai. Univ. Eng. Sci. 2009, 23, 106-110. (In Chinese)

74. Xie, D.H. Discussion on the heating method of natural gas as a gas source in the new countryside. China High-Tech Enterp. 2017, 5, 112-113. (In Chinese)

75. Han, G.; Wang, Z.W.; Bai, W.; Zhao, B.Z.; Zhu, J.L. Thermal economic analysis on wall-mounted gas boiler. Henan Sci. 2008, 27, 1260-1263. (In Chinese)

76. Cui, J. Study on Wall-Mounted Boiler Heating System in the Middle and Lower Reaches of the Yangtze River Region. Master's Thesis, Qingdao University of Technology, Qingdao, China, 2015.

77. Li, Z.; Tong, L.Z.; Sun, J. Comparison and analysis of individual type wall-mounted gas boilers heating and central heating of residential buildings. Ind. Boiler 2013, 29, 30-33. (In Chinese)

78. Zhi, C.Y.; Zhao, Y.H. Experimental research on solar coupled ground source heat pump heating system. Build. Energy Effic. 2017, 45, 49-51. (In Chinese)

79. Emmi, G.; Zarrella, A.; Carli, M.D.; Galgaro, A. An analysis of solar assisted ground source heat pumps in cold climates. Energy Convers. Manag. 2015, 106, 660-675. [CrossRef]

80. Yang, W.B.; Zhang, H.; Liang, X.F. Experimental performance evaluation and parametric study of a solar-ground source heat pump system operated in heating modes. Energy 2018, 149, 173-189. [CrossRef]

81. Ozgener, O.; Hepbasli, A. Experimental performance analysis of a solar assisted ground-source heat pump greenhouse heating system. Energy Build. 2005, 37, 101-110. [CrossRef]

82. Liang, C.H.; Zhang, X.S.; Li, X.W.; Zhu, X. Study on the performance of a solar assisted air source heat pump system for building heating. Energy Build. 2011, 43, 2188-2196. [CrossRef]

83. Bellos, E.; Tzivanidis, C. Energetic and financial sustainability of solar assisted heat pump heating systems in Europe. Sustain. Cities Soc. 2017, 33, 70-84. [CrossRef]

84. Deng, J.; Tian, Z.Y.; Fan, J.H.; Yang, M.; Furbo, S.; Wang, Z.F. Simulation and optimization study on a solar space heating system combined with a low temperature ASHP for single family rural residential houses in Beijing. Energy Build. 2016, 126, 2-13. [CrossRef]

85. Li, H.; Xu, W.; Yu, Z.; Wu, J.L.; Yu, Z.Y. Discussion of a combined solar thermal and ground source heat pump system operation strategy for office heating. Energy Build. 2018, 162, 42-53. [CrossRef]

86. Li, N.; Tian, X.; Wang, J.T.; Xu, J.F. Operation performance of air-source heat pump assisted solar heating system in Beijing rural residence. Heat Vent. Air Cond. 2017, 47, 136-140. (In Chinese)

87. Shan, M.; Yu, T.; Yang, X. Assessment of an integrated active solar and air-source heat pump water heating system operated within a passive house in a cold climate zone. Renew. Energy 2016, 87, 1059-1066. [CrossRef]

88. Shen, Z.Y.; Xuan, Y.M. Energy consumption analysis of solar assisted air source heat pump heating and hot water system. Refrig. Air Cond. 2016, 30, 544-548. (In Chinese)

89. Dai, L.H.; Li, S.F.; DuanMu, L.; Li, X.L.; Shang, Y.; Dong, M. Experimental performance analysis of a solar assisted ground source heat pump system under different heating operation modes. Appl. Therm. Eng. 2015, 75, 325-333. [CrossRef]

90. Wang, S.; Liu, Y.F.; Ma, C. Study on the soil thermal response of sgchpss. Acta Energ. Sol. Sin. 2015, 36, $2578-2583$. (In Chinese)

91. Tang, Z.W.; Cai, B.; Zhang, H.Y.; Han, Y.F. Experiment on the Solar Energy and Buried Pipe Heat Pump Joint Heating. J. Beijing Univ. Technol. 2014, 40, 950-953. (In Chinese)

92. Zhang, W.; Zhu, J.L.; Hu, T. Experimental research on solar-ground source heat pump heating system. Acta Energ. Sol. Sin. 2011, 32, 496-500. (In Chinese) 
93. Jing, F.; Wang, W.; Zhang, X. Solar Kang heating system for cold areas. Low Temp. Archit. Technol. 2006, $28,113-115$. (In Chinese)

94. Zhao, D.S.; Ji, J.; Yu, H.C.; Zhao, X.D. A study on thermal characteristic and sleeping comfort of a hybrid solar heating system applied in cold rural areas. Energy Build. 2019, 182, 242-250. [CrossRef]

95. Wei, W.; Ji, J.; Luo, C.L.; Wang, Y.Q.; Guo, C. Experimental study of a combined solar Kang system operation mode. Acta Energ. Sol. Sin. 2017, 38, 806-812. (In Chinese)

96. Guo, M.; Ma, X.Q.; Ge, M.Y.; Yue, Y.M.; He, X.; Wang, Y.M. Primary study on the design and experiment of energy storage Kang of solar phase change material. Energy Conserv. 2017, 62-64. (In Chinese) [CrossRef]

97. Chang, S.; Madani, H.; Palm, B. Heating solutions for residential buildings in China: Current status and future outlook. Energy Convers. Manag. 2018, 177, 493-510. [CrossRef]

98. Karytsas, S. An empirical analysis on awareness and intention adoption of residential ground source heat pump systems in Greece. Energy Policy 2018, 123, 167-179. [CrossRef]

99. Zhang, C.; Kotani, K.; Saijo, T. Public acceptance of environmentally friendly heating in Beijing: A case of a low temperature air source heat pump. Energy Policy 2018, 117, 75-85. [CrossRef]

100. Karytsas, S.; Theodoropoulou, H. Public awareness and willingness to adopt ground source heat pumps for domestic heating and cooling. Renew. Sustain. Energy Rev. 2014, 34, 49-57. [CrossRef]

101. Li, B.Z.; Du, C.Q.; Yao, R.M.; Yu, W.; Costanzo, V. Indoor thermal environments in Chinese residential buildings responding to the diversity of climates. Appl. Therm. Eng. 2018, 129, 693-708. [CrossRef]

102. Shao, N.; Ma, L.; Zhang, J. Study on the rural residence heating temperature based on the residents behavior pattern in South Liaoning province. Energy Build. 2018, 174, 179-189. [CrossRef]

103. Yao, R.M.; Costanzo, V.; Li, X.Y.; Zhang, Q.L.; Li, B.Z. The effect of passive measures on thermal comfort and energy conservation. A case study of the hot summer and cold winter climate in the Yangtze River region. J. Build. Eng. 2018, 15, 298-310. [CrossRef]

(C) 2018 by the authors. Licensee MDPI, Basel, Switzerland. This article is an open access article distributed under the terms and conditions of the Creative Commons Attribution (CC BY) license (http:/ / creativecommons.org/licenses/by/4.0/). 